\title{
Environmental Triggers of Autoreactive Responses: Induction of Antiphospholipid Antibody Formation
}

\section{OPEN ACCESS}

Edited by:

Kenneth Michael Pollard, The Scripps Research Institute,

United States

Reviewed by:

Howard A. Young, National Cancer Institute at Frederick,

United States

Laura Andreoli,

University of Brescia, Italy

${ }^{*}$ Correspondence:

Rustam Aminov

rustam.aminov@gmail.com

Gayane Manukyan

gaya.manukyan@gmail.com

g_manukyan@mb.sci.am

Specialty section:

This article was submitted to Autoimmune and Autoinflammatory

Disorders,

a section of the journal

Frontiers in Immunology

Received: 28 March 2019 Accepted: 27 June 2019 Published: 10 July 2019

Citation:

Martirosyan A, Aminov $R$ and Manukyan G (2019) Environmental Triggers of Autoreactive Responses: Induction of Antiphospholipid Antibody

Formation. Front. Immunol. 10:1609. doi: 10.3389/fimmu.2019.01609

\author{
Anush Martirosyan ${ }^{1,2}$, Rustam Aminov ${ }^{3 *}$ and Gayane Manukyan ${ }^{1,2 \star}$ \\ ${ }^{1}$ Laboratory of Molecular and Cellular Immunology, Institute of Molecular Biology, Yerevan, Armenia, ${ }^{2}$ Russian-Armenian \\ (Slavonic) University, Yerevan, Armenia, ${ }^{3}$ School of Medicine, Medical Sciences and Nutrition, University of Aberdeen, \\ Aberdeen, United Kingdom
}

Antiphospholipid antibodies (aPLS) comprise a diverse family of autoantibodies targeted against proteins with the affinity toward negatively charged phospholipids or protein-phospholipid complexes. Their clinical significance, including prothrombotic potential of anti-cardiolipin antibodies (aCLs), anti- $\beta 2$-glycoprotein I antibodies (aß2-GPIs), and lupus anti-coagulant ( $\llcorner A)$, is well-established. However, the ontogeny of these pathogenic aPLs remains less clear. While transient appearance of aPLs could be induced by various environmental factors, in genetically predisposed individuals these factors may eventually lead to the development of the antiphospholipid syndrome (APS). Since the first description of APS, it has been found that a wide variety of microbial and viral agents influence aPLs production and contribute to clinical manifestations of APS. Many theories attempted to explain the pathogenic potential of different environmental factors as well as a phenomenon termed molecular mimicry between $\beta 2-\mathrm{GPI}$ molecule and infection-relevant structures. In this review, we summarize and critically assess the pathogenic and non-pathogenic formation of aPLs and its contribution to the development of APS.

Keywords: antiphospholipid antibodies, antiphospholipid syndrome, bacteria, viruses, vaccination, drugs

\section{INTRODUCTION}

Antiphospholipid antibodies (aPL) comprise a diverse family of heterogeneous autoantibodies targeting proteins with the affinity toward negatively charged phospholipids or protein-phospholipid complexes. aPLs are increasingly being recognized as causative factors of antiphopholipid syndrome (APS) manifestations. Syndrome is defined by persistent aPL positivity accompanied by thromboembolic events and/or obstetrical complications (1).

While a broad spectrum of aPL exists, the presence of anti- $\beta 2$ glycoprotein I (anti- $\beta 2 \mathrm{GPI}$ ) antibodies, anticardiolipin $(\mathrm{aCL})$, and lupus anticoagulant (LA) is accepted as independent risk factors for the episodes of vascular thrombosis and pregnancy loss in APS $(2,3)$. aPL are responsible for the alterations in the mechanisms of coagulation and fibrinolysis, leading to a proinflammatory, or hypercoagulable state. Beyond the heterogeneity of different aPL, it is widely accepted that they represent a bulk of natural antibodies (mainly IgG and IgM classes) with low affinity, generated for the most part by B1 cells (4). Pathogenic role of aPL was shown in animal studies $(5,6)$. In mice, the passive transfer of aPL produced features resembling human APS, that is, fetal loss and thrombotic events (7). Another evidence for the pathogenicity of autoantibodies was obtained in studies proving a substantial clinical improvement after the removal of autoantibodies by plasma exchange or plasmapheresis (8). Mechanistically, we demonstrated 
the restoration of monocyte transcriptional activity in patients with APS after plasmapheresis (9).

The presence of aPL is not necessarily associated with the primary APS; they could be detected in a variety of clinical conditions, including different autoimmune diseases, infections, neoplasms, after vaccination or drug use, etc., and could also be transiently expressed in healthy individuals (3). In autoimmune disorders, aPL are mainly cofactor dependent and require the presence of phospholipid-binding proteins, such as $\beta 2$ GPI and prothrombin, which are their main targets, while aPL generated after infections are largely cofactor independent (10).

Based on the currently available clinical and experimental evidence, it is likely that in predisposed individuals, different environmental triggers may eventually lead to the production of aPL, which then can lead to the development of APS. Several theories tried to explain the pathogenic potential of different environmental factors as well as a phenomenon termed molecular mimicry between $\beta 2 \mathrm{GPI}$ molecule and infection-relevant structures. This review summarizes current findings on the origin and mechanisms of production of APS-associated antibodies and compiles the recent advances toward understanding the functional relevance of aPL to the development of APS.

\section{VIRUSES}

Among a wide range of infectious agents, which may contribute to the increase of aPL, human immunodeficiency virus (HIV) and hepatitis $\mathrm{C}$ virus (HCV) are among the most frequently reported. HIV infection, association of which with aCL antibodies has been first reported more than 30 years ago (11), currently remains the most frequent infectious cause for aPL production in adult and pediatric patients. A considerable diversity of aPL can be detected in HIV-infected individuals, including aCL, anti- $\beta 2$ GPI, LA, aPT, aPS, aPI, and aPC $(12,13)$. The aCL antibodies during HIV infection could be of both pathogenic type ( $\beta 2$ GPI cofactor dependent) and post-infectious type (non$\beta 2 \mathrm{GPI}$ dependent). The estimated incidence of IgG aCL among HIV-positive individuals is in the range of 7-94\% (mean 46.5\%) compared to $1.98 \%$ in control subjects (13). IgM aCL are less common and their clinical significance remains controversial (14). Both positive (15) and negative (14) associations between $\mathrm{aCL}$ and thromboembolic phenomena in patients were reported, although aPL-related clinical features are generally uncommon in HIV patients (16). The latter may be explained by the ability of $\beta 2 \mathrm{GPI}$ to inhibit the interaction between HIV-specific IgG aPL antibodies and CL, which was demonstrated in the competition study designed to delineate the true autoimmune and non-pathogenic aPL (17). Further assessment of the binding specificity and avidity of aPL antibodies in HIV showed low antibody avidity (18). Except for a low incidence of anti$\beta 2 \mathrm{GPI}$, the prevalence of aCL, aPS, aPI, and aPC antibodies in HIV-1 infection was comparable to that found in APS, indicating the tendency to recognize various phospholipids other than $\beta 2$ GPI (18). It is likely that the relatively low levels of anti- $\beta 2$ GPI and cofactor-independent nature of HIV-specific aPL, compared to the autoimmune one, accounts for the rare incidence of APS among HIV-positive individuals. The frequency and complications of LA may vary considerably among HIVinfected patients. Reported incidences are in the range of $0-72 \%$ (19), but the pathogenic association with thrombosis is somewhat exceptional (15).

Similarly to HIV, aCL antibodies are the most common type of aPL in HCV infection. A high prevalence of aCL in $\mathrm{HCV}$ patients compared to healthy controls has been reported $(18.6 \%$ vs. $1.78 \%$ ) (13). aCL from these patients showed no $\beta 2 \mathrm{GPI}$ dependency, and association with the thromboembolic events was weak (15). An earlier study demonstrated that aCL due to HCV exhibit features of natural polyspecific autoantibodies, suggesting their non-pathogenic nature (20). High incidence of LA presumably predispose the occurrence of thrombotic complications in a small subset of $\mathrm{HCV}$-positive APS patients, since in an unselected cohort of HCV-infected individuals the presence of LA is a rare event (21). Albeit other hepatitis viruses were less intensively studied in term of aPL, occurrence of aCL in both HBV and HDV infection have been suggested to interfere with thrombotic incidence in patients with hepatitisrelated hepatocellular carcinoma (22).

High frequency of HIV- and HCV-induced aPL in terms of a possible association with APS is highly attractive but also controversial. Analyses of the spectrum of clinical features related to APS (peripheral thrombosis, valvular heart disease, nephropathy, etc.) in patients with chronic HIV/HCV infections suggested that while in individual cases these infections may lead to the development of a true APS, in most cases the presence of aPL and relevant clinical manifestation might merely represent an epiphenomenon secondary to the chronic immune stimulation by the virus (21). In several documented cases, thrombotic episodes in HIV, or HCV-infected patients were linked to extrinsic causes (antiretroviral treatment and opportunistic infections), suggesting a limited role of aPL in these events (12). Analogously, HIV-associated vascular damage, endothelial dysfunction and pulmonary embolism may well mimic clinical presentation of APS. In the case of HCV, immunological markers of chronic infection such as ANA, cryoglobulins, hypocomplementemia, and rheumatoid factor may potentially contribute to the development of symptomatic features resembling APS.

In the light of remarkable similarities in the clinical manifestations of patients with parvovirus B19 infection, autoimmune systemic lupus erythematosus (SLE), and/or APS such as thrombosis, hemolytic anemia, spontaneous abortion, livedo reticularis, and arthritis, B19 infection is considered as an initial trigger for autoimmune processes (23). Development of pathogenic aPL has been often reported as being associated with this infection. In particular, over a quarter of children with rheumatic diseases were found to be positive for aPL and also had B19 parvovirus infection, presently or in the past (24). The most notable characteristic of aPL, detected in patients infected with parvovirus B19, is the enhanced antigenbinding ability in the presence of $\beta 2 \mathrm{GPI}$ as a cofactor (25). Antibodies present in the serum of B19-infected patients are predominantly of the IgG isotype, they are specific toward the negatively charged phospholipids, aCL and phosphatidyl serine (aPS) and, on rare occasions, to the neutral phospholipid phosphatidyl ethanolamine (aPE). Based on these observations, 
it has been suggested that the nature of B19-induced aPL is markedly different from the antibodies generated in response to other viral infections. Their binding ability, isotype distribution, and cofactor dependence resemble those present in patients with autoimmune diseases, pointing to the potential role of B19 in triggering autoimmune events (25). To our knowledge, there have been at least two reported cases of thrombotic events associated with parvovirus B19 infection: a male patient who developed splenic infarction and a female patient with multiple pulmonary emboli $(26,27)$. Both cases were characterized by the transient presence of aPL antibodies of IgM or IgG isotypes. Mechanisms responsible for the aPL production during B19 infection are: cross-reactivity between anti-B19 IgG antibodies with multiple human autoantigens (cardiolipin, collagen II, keratin, angiotensin II type 1 receptor, and platelet membrane glycoprotein IIb/IIIa), presentation of apoptosis-associated selfantigens by infected cells (23), and phospholipase-A2-like activity observed in the VP1 unique region of the structural protein VP1 (24).

Viral agents that are less frequently reported as provoking a transient or permanent rise of aPL include the human herpesviruses such as cytomegalovirus (CMV), varicella-zoster virus (VZV), and Epstein-Barr virus (EBV) (28). They are common viral pathogens with the estimated seroprevalence among adult population $>90 \%$ (29). These three viruses have been implicated in the presence of aPL and aPL-related clinical manifestations. An intriguing association between infection and aPL was revealed in pregnant women who underwent routine prenatal screening for toxoplasmosis, rubella, cytomegalovirus, and herpes simplex virus (TORCH panel). Substantial proportion of healthy pregnant women $(52.2 \%)$ with false-positive TORCH appeared to be aPL positive (30). Another study has summarized the findings on thrombosis associated with CMV infection: among 97 patients who developed CMV-induced thrombosis 14 had transient or permanent APS (31). aPL-independent mechanisms responsible for CMV-triggered procoaguable state include activation of coagulation factors and platelets, adhesion of leukocytes as a sequel to the direct vascular endothelial damage by the virus (32), generation of thrombin or factor VIII, and/or down-regulation of physiological anticoagulant mechanisms (33). Another cross-sectional study, with 95 children enrolled, showed a transient increase of LA and aCL in 43 children following varicella infection (34). Moreover, a direct pathogenic role of VZV-induced transient increase of IgM/IgG aCL, IgM anti-b2GPI, or LA in the development of hypercoaguable state was suggested for a number of pediatric and adult cases with thrombotic or vascular complications (35-37). Exposure to EBV was associated with a lupus phenotype and promoted autoimmune processes (38). The main type of aPL detected in EBV infection was aCL IgG (39). In favor of pathogenic nature of aPL is the case described in the report by Delbos et al., who described CMV-induced thrombosis in a previously healthy woman with a pulmonary embolism in the presence of aPL (40).

Adenovirus infection is also associated with a significant increase of aCL. aCL-specific IgG and IgM classes were found in a half of children with respiratory disease caused by adenoviral infection (41). Transitory increase of LA, aCL, and antiphosphatidylserine-dependent antithrombin antibodies (aPS/PT) was observed in a 9-year-old girl following acute gastroenteritis (due to adenovirus) and pneumonia (due Mycoplasma pneumoniae) (42). Herpes simplex virus, dengue virus, human herpes virus 6, rubella, measles, chicken pox, and mumps infections are usually accompanied by a relatively low level of autoantibodies, which are often declined after the elimination of infection and are not associated with thrombosis incidences (28).

Initial encounter between a virus and a target cell occurs at the plasma membrane interface. Negatively charged phospholipids, along with low-density lipoprotein receptors and gangliosides, have been shown to play a role in the entry of numerous viruses (43). Most enveloped viruses, including retroviruses, acquire their lipid envelope by budding through the cellular membrane. For example, HIV uses phosphatidylserine (PS) as a cofactor for infection and acquires this phospholipid from lipid rafts during budding (44). A comprehensive survey of total lipid composition of retroviral envelopes revealed a considerable resemblance with that of the plasma membrane, unless they were highly enriched in specific negatively charged phosphoinositides, PIP and PIP2, which are phosphorylated derivatives of phosphatidylinositol (45). Additionally, viruses use the host lipids in the later stages of infection to promote intracellular trafficking, replication, viral assembly, and egress. RNA and DNA viruses that replicate in the cytosol tend to entail membranes of specific cellular compartments (e.g., endoplasmic reticulum, mitochondria, endosomes, lysosomes, or Golgi bodies) (46). Despite that the mitochondrial disturbances are prevalent among HIV-infected individuals, interaction of the virus with host mitochondrial CL has not been tested yet. However, demonstration of in vitro CL cross-reactivity with HIV-specific neutralizing antibodies (47) has inspired researchers to analyze the correlation between the occurrence of HIV-specific aCL and viral parameters. It was shown that aCL, detected in HIV patients, are strongly and independently associated with the level of virus replication, regardless of the disease stage (48). In another case report, initially high titers of $\mathrm{aCL}$ and anti- $\beta 2 \mathrm{GPI}$ in a HIV-positive man were shown to progressively decrease, in parallel with a viral load (49).

It seems that entangled and interactive relationships between the viral infection and the host immune system mediate diversity of aPL responses and related manifestations. Despite the mounting evidence supporting the contribution of infection agents to production of autoantibodies, aPLrelated complications in the context of viral infection are rare. Thus, the development of true APS is exceptional, excluding the cases when autoimmunity is present prior infection. In this context, the assessment of $\beta 2 \mathrm{GPI}$ dependence could be helpful in differentiating the pathogenic autoimmune aPL from post-infectious one.

\section{BACTERIA}

It is a widely accepted view that pathogenesis of many autoimmune diseases is largely driven by inappropriate or inadequate immune responses toward bacterial agents $(50,51)$. 
Similarly, a number of Gram-positive and Gram-negative bacteria are recognized as being linked to aPL production. Despite this, transitory increase of bacteria-induced aPL autoantibodies was only occasionally associated with thrombotic events (52).

M. pneumoniae and Streptococcus spp. infections, which are among the most prevalent bacterial infections in children and young adults, were linked to the occurrence of aPL. A significant increase in aCLof IgM and IgG classes was found in patients with $M$. pneumoniae, especially in those with severe infection or with cold hemagglutinins (53). Almost a half of patients with poststreptococcal glomerulonephritis were positive for aCL, with a long-term persistence of the antibodies in the majority of patients, but with no thromboembolic events (54). A case of childhood-onset autoimmune APS and several pediatric cases of aPL-related thromboembolic complications at various anatomical sites were all attributed to the pulmonary M. pneumonia infection (55-57). Two independent studies reported splenic infarctions secondary to aPL positivity due to M. pneumoniae or Staphylococcus spp. infection $(58,59)$.

Another evidence for aPL-mediated thrombosis as a consequence of microbial infection has been recently described in Lemierre syndrome (60). This a rare and potentially lifethreatening condition characterized by thrombophlebitis of the internal jugular vein and pulmonary embolism (61). The syndrome is classically associated with an anaerobic bacterium Fusobacterium necrophorum, although a variety of other bacteria such as streptococci, staphylococci, and enterococci may be also responsible for the disease (61).

Examination of serum samples from leprosy patients demonstrated the presence of LA and aPT, with the prevalence of anti- $\beta 2 \mathrm{GPI}(62,63)$, as well as the heterogeneity of aCL in regards to co-factor dependency (64). Some authors have suggested similarities between the leprosy-mediatedaPL with those found in patients with autoimmune diseases (65). Nevertheless, leprosyspecific aPL are infrequently associated with the thrombotic features. Several exceptional cases of microvascular thromboses, related to $\beta 2 \mathrm{GPI}$-dependent aCL, were documented in patients who developed a rare Lucio's phenomenon on a background of diffuse lepromatous leprosy (66).

Although somewhat controversial, syphilis infection has also been associated with the production of aPL. The reported prevalence of syphilis-related aCL is wide-ranging, varying from 8 to $67 \%$, which may be attributed to their cross-reactivity with treponemal cardiolipins (13). Nevertheless, the presence of anti$\beta 2$ GPIand LA and thrombotic episodes are uncommon in this infection (13).

The pathogenic potential of aPL found in patients infected by Mycobacterium tuberculosisis contentious. Poly-reactive B1 cells were shown as the main source of non-specific anti-phospholipid IgM antibody produced in response to M. tuberculosis lipids which suggests non-pathogenic nature of these aPL (67). In support of this assertion no association of aPL levels with thrombotic events was reported. The increased levels of aCLspecific IgM and IgG isotypes were found in several populationbased cohort studies (68-70). Elkayam et al. (71) were first to reveal the elevated level of anti- $\beta 2$ GPI in a substantial proportion of tuberculosis patients, which is declined following TB therapy (71). Similarly, the normalization of IgM class of aCL, antiphosphatidyl inositol (aPI), antiphosphatidyl ethanolamine (aPE), antiphosphatidyl choline (aPTC), and antisphingolipid (aSL) antibodies in the sera of tuberculosis patients following TB therapy was reported (72).

Presently it is widely accepted that infection by Helicobacter pylori is the most common cause of chronic gastritis (73). Both the pathogenic and protective roles for this infection in different autoimmune diseases were suggested (74). A first large-cohort study has been performed to estimate the prevalence of antiH. pylori (anti-HP) antibodies in 1,290 patients diagnosed with 14 different autoimmune diseases, including 157 primary and secondary APS patients, and 385 matching healthy controls (75). All subjects were screened for the presence aPL. The study uncovered the highest frequency of anti-HP IgG and significantly elevated levels of aCL IgM among the patients with primary APS (75). Another study demonstrated a causal relationship between $H$. pylori infection and aCL of all isotypes IgA/IgM/IgG in 84 children, with a decline of autoantibody titers following eradication of $H$. pylori (76).

\section{YEASTS AND FUNGI}

The role of yeasts and fungi in APS has not gained too much attention and thus the cases of fungal-induced aPL are very rare in the literature (28). Recent findings have raised wariness regarding a pathogenic potential of food products prepared with the use of Saccharomyces cerevisiae, known as Brewer's and Baker's yeast (77). Anti-S. cerevisiae antibodies (ASCAs), directed against the phosphopeptidomannan, have been demonstrated to be prevalent among aPL-positive autoimmune patients, including those with Crohn's disease (78), SLE (79), RA (80), and APS (81). The presence of cross-reactive epitopes on $\beta 2 \mathrm{GPI}$ and $S$. cerevisiae $(77,81)$ and the fact that ASCAs tend to appear years before the fully developed autoimmune conditions (82) point to a possible pathogenic significance of ASCAs in APS.

\section{COMMENSAL MICROBIOTA}

Besides directly affecting the host, diet may exert indirect influence via modulating the composition and function of the gut microbial communities. Ingestion of probiotics, for instance, is considered to be beneficial for modulation and/or restoration of the gut microbiota, and it is capable of altering the course of autoimmune diseases and APS. For example, consumption of probiotic fermented milk products in $\beta 2 \mathrm{GPI}-$ immunized Balb/c mice resulted in a decline of serum anti$\beta 2$ GPI titers and in the shift from Th2 type immune response toward Th1 (83). Based on above-mentioned observations, a role for commensal bacteria was hypothesized (84). Indeed, a report by Aguiar and coworkers has shown a specific change in the gut microbial composition in APS patients. Particularly, a decrease of bacteria belonging to the genus Bilophila and overgrowth of bacteria of the Slackia genus were shown 
(85). Moreover, anti-domain I (DI) $\beta 2$ GPI IgG positivity in APS patients correlated significantly with the enrichment by Slackia spp. and by the lower abundance of butyrate-producing Butyricimonas (85). Reduction in microbe-derived butyrate, which has an anti-inflammatory and immunomodulatory activity (86), may enable a stronger T-cell proliferative response against $\beta 2 \mathrm{GPI}$. Antigen-specific response toward gut microbiota was proven by the administration of broad-spectrum antibiotics in APS-prone (NZWxBXSB)F1 mice, which diminished the proliferation of $\beta 2$ GPI-reactive $T$ cells but not of anti-CD3 (87). These microbiota-depleted animals showed a higher survival rate due to the prevention of thrombotic events and suppression of serum anti- $\beta 2 \mathrm{GPI}$ IgG titers. In further developments, a specific Gram-positive candidate bacterium, involved in immune cross-reactivity, has been identified based on in silico analysis. Common colonic butyrate-producing Roseburia intestinalis shared a high degree of sequence homology with both the major B and T cell epitopes to $\beta 2$ GPI (84). The evidences of the involvement of commensal microbiota in aPL production are sporadic and mainly published as preliminary results which does not allow us to fully estimate their contribution. Need to reiterate here though that under the normal conditions the epitopes of commensal bacteria are not usually exposed to the adaptive arm of the immune system. Response to the epitopes of commensal microbiota may appear only if the epithelial barrier function is compromised thus allowing elevated translocation of bacteria and the exposure of epitomes that are usually not encountered under the normal circumstances.

Commensal bacteria may act in several ways to modulate immune reactions. Initiation of an autoimmune reaction by gut commensals is likely to engage the mechanisms similar to that of pathogenic microbiota. Among the different potential scenarios, cross-reactivity triggered by commensal cardiolipin seems to be most intriguing. Cardiolipin is an ancient phospholipid universally found in energy transducing membranes of both prokaryotes and eukaryotes, albeit at different locations (88). In eukaryotes $\mathrm{CL}$ is found almost exclusively in mitochondria, while bacterial CL is found in the plasma membranes (89), which reflects the endosymbiotic origin of mitochondria. Given the fact that human CL is normally sequestered from the immune system but the aCL antibodies are broadly prevalent among infected/autoimmune patients, bacterial CL could be considered as a potential damage-associated molecular pattern (DAMP). Thus, it is reasonable to assume that CL-containing bacteria, among which Gram-positives are especially enriched with CL (90), can act as a source of persistent cross-reactive antigens in a genetically susceptible host with a compromised self-tolerance. Spectroscopic analysis has demonstrated a conformational change in $\beta 2 \mathrm{GPI}$ upon binding to CL, resulting in generation of highly immunogenic epitopes within $\beta 2 \mathrm{GPI}$ capable of mounting an autoimmune response (91). Therefore, it could be assumed that the initial pathology, which exposes the normally sequestered endogenous and bacterial CLs, may then lead to the recognition by the DAMP receptors and generation of different aPL subpopulations in respect to cofactor dependency.

\section{VACCINES}

Increased medical and public interest toward the safety of vaccination has been heightened following several reports of possible post-vaccination complications involving autoimmune reactions. Causal relationship between several vaccines and autoimmune responses has been reported in numerous studies, among which influenza vaccination is the most frequently reported in the context of aPL generation.

In two pediatric case reports a transient appearance of aPL following inactivated influenza vaccination was demonstrated. A 5-year-old boy and 5-year-old girl were both diagnosed with Henoch-Schönlein purpura (HSP), with the presence of aPL antibodies $(92,93)$. The involvement of bacterial and viral infections was excluded based on laboratory analyses. The girl presented with a palpable purpuric rash and severe abdominal pain about 12 days after immunization (93). Two months later, her blood was negative for aCL or LA. After 4 months, second immunological examination revealed elevated IgG aCL antibodies. Similar symptoms, accompanied by elevated antiinfluenza $\mathrm{A} / \mathrm{H} 3 \mathrm{~N} 2$ antibody, were presented in the boy on the second day after vaccination. Initial palpable purpura, abdominal and ankle pain was successfully improved after a month of oral corticosteroid therapy. Levels of aCL IgG antibody declined within a month, and LA disappeared 2 months after hospital discharge (92).

An association between influenza immunization and systemic autoimmune features was studied in 24 female patients with SLE (94). Six weeks after the vaccine administration, high titers of antibodies reacting with $\mathrm{Sm}, \mathrm{Sm} / \mathrm{RNP}$, Ro, and La antigens were found, with a reduction in titers after 12 weeks follow-up. Another study of post-vaccination events in SLE patients, with and without former aPL positivity, revealed some mild clinical side-effects and increased levels of anti- $\beta 2$ GPI antibodies of IgG and IgM isotypes after repeated annual influenza vaccination (95). The findings suggested that in clinically stable SLE influenza vaccination may increase the risk of thrombotic manifestations (95). Kinetics of aCL, anti-B2GPI, LA, anti-ENA, and ANA autoantibodies, induced by seasonal influenza vaccination, was analyzed in a large group of healthy adults (96). Increased levels of autoantibodies were found in 15\% of participants 1 month after the immunization (96). Six months later, increased levels of autoantibodies remained in 13\% of participants suggesting potential long-term effects of influenza vaccination including the risk of thrombotic manifestations.

Although several reports suggested induction of aPL following seasonal and pandemic influenza vaccination, examination of the literature in this field revealed conflicting reports. Vista et al. (97) investigated a large cohort $(n=101)$ of SLE patients and matching controls $(n=101)$ at baseline and 2, 6, and 12 weeks after receiving seasonal influenza vaccination. The study showed a post-vaccination increase of aCL but without the increased onset of $\beta 2$ GPI (97). Another study, which employed a large panel of autoantibodies for screening, investigated 45 primary APS patients and 33 healthy controls after A/H1N1 non-adjuvant vaccine administration. In contrary to the previous study, they failed to find short- or long-term sequelae involving a significant 
increase of aPL-related antibodies and thrombosis, suggesting that influenza vaccine, at least without adjuvant, is safe (98).

Several case reports raised concerns over a possible association between the vaccine-induced transitory autoimmune responses and the onset of neurological symptoms. An acute confusion state accompanied by severe headache, a middle cerebral artery occlusion, vasculitis, and thrombocytopenia were developed in a 55-years old woman, soon after receiving an influenza vaccine (99). This patient was diagnosed with SLE and secondary APS based on clinical findings and positive for anti-dsDNA, ANA, IgG aCL, and LA. Other two cases of elevated serum IgG antiphosphatidylcholine antibodies were described in two female pediatric patients with a sudden onset of bilateral optic neuritis due to the administration of trivalent inactivated influenza vaccine (100).

There are only few indications of a possible effect of other types of vaccines on induction of aPL autoantibodies. Fluctuations of aCL, LA, and anti-B2GPI were seen in the minority of participants $(n=8 / 85)$ after a month following hepatitis B vaccination, with a decline of post-vaccination titers 5 months later (101). Manifestation of definitive APS was proven in a young male as a long-term consequence of diphtheria-tetanus toxoid vaccination (102). The patient experienced thrombotic event accompanied with the stable high LA titer over the next 3 months. Another clinically and serologically proven case of APS was a 13-year-old girl who received a quadrivalent human papillomavirus (HPV) vaccine (103). Acute thrombocytopenia and bleeding were rapidly improved although positive titers of aPL persisted for 6 months.

Among other vaccines, the strongest experimental evidence for post-vaccination development of aPL was revealed for tetanus toxoid (TTd) vaccine. In mouse models, APS manifestation was achieved by immunization of mice with TTd using different adjuvants $(104,105)$. In humans, an evidence of anti- $\beta 2 \mathrm{GPI} /$ anti-tetanus toxoid cross-reactive antibody generation after vaccination with TTd in two healthy men was reported (106).

Clearly, vaccines should share molecular patterns with pathogens to elicit protective immune responses. The overall reported frequency of aPL incidences after influenza immunization, however, is higher than after infection (our survey of the published literature). Whether this phenomenon is due to the better studied cohort of vaccinated individuals or to the increased sensitivity to concomitant stimuli such as adjuvants remains unknown. Recently, Shoenfeld and AgmonLevin suggested to group several autoimmune conditions in a single entity called "ASIA"-Autoimmune (Autoinflammatory) Syndrome Induced by Adjuvants," which is triggered by external agents such as infections and vaccines (107). It has to be noted, however, that the effects of adjuvants could be significant only in genetically predisposed individuals, whilst less so in general population.

\section{DRUGS}

Evidence for a possible association of aPL production and drug administration was first described in 1945 in a patient, who developed a lupus-like syndrome presumably following sulphadiazine therapy (108). Currently a wide range of pharmacological agents used to treat arrhythmia, psychological disorders, hypertension, bacterial infections, epilepsy, or other convulsions, etc. could be implicated in the production of aPL and, in some cases, development of clinically significant APS manifestations (109). Pathogenic potential and clinical manifestations related to drugs-induced aPL are variable and largely dependent on the specific nature of a drug under question. The majority of the drug-induced aPL are usually considered to be fairly benign and disappear after the drug withdrawal (110). aPL induction by procainamide, adalimumab, interferon- $\alpha$ and several other drugs, however, may be linked to the development of thrombosis (111).

Antiarrhythmic agents, including procainamide, and quinidine have been frequently associated with the development of aPL, predominantly LA. Summarizing the relevant studies published between 1976 and 1998, Dlott and Roubey (109) have revealed the features suggestive or consistent with drug-induced LA in 13 of 42 reported cases. The authors highlighted the clinical presentation of thrombosis in 11 cases that could be associated with the underlying cardiac or vascular pathologies for which the patients were prescribed procainamide (109). Generation of $\beta 2 \mathrm{GPI}$-dependent IgG aCL after the administration of procainamide resulted in thrombosis and, in one case, of the drug-induced APS (112). A number of studies demonstrated association between quinidine and its stereoisomer quinine and the occurrence of LA (113-115), while the occurrence of aCL was only rarely detected (116). Several mechanisms have been proposed to explain the link between antiarrhythmic drugs and aPL induction. The most plausible among these is a non-specific interaction of antiarrhythmic agents with membrane phospholipids, situated close to the sodium channels, which may trigger an initial event leading to self-reactivity (117).

Pharmacological efficiency of antipsychotic drugs is related to the toxic effects imposed by their non-specific interaction with the phospholipid bilayer, particularly with negatively charged lipids (118). Chlorpromazine (CPZ) is the agent most often implicated in cases of drug-induced aPL (109). LA, which is the main type of aPL antibodies found to be associated with CPZ, is rarely reported as the cause of thrombosis (109). Incidence of aCL alone or together with LA, following $\mathrm{CPZ}$ administration, was described in two separate studies $(110,119)$. Gharavi et al.(17) examined $\beta 2 \mathrm{GPI}$-dependence of aPL, which is triggered by $\mathrm{CPZ}$, and found its resemblance with autoimmune type antibodies (17). In another study, however, the presence of aCL, anti- $\beta 2 \mathrm{GPI}$ or LA was detected in patients with psychiatric diseases regardless of treatment by CPZ or other antipsychotics (120).

Besides antimicrobial activities, antibiotics may impose substantial interference with the host physiology and metabolism (121). Amoxicillin (111) and streptomycin (113) were the first antibiotics associated with the LA activity. In a later study, production of transient IgG aCL in response to sulfasalazine has been reported (122). There has been a renowned interest regarding the influence of antibiotics on aPL formation. Two studies reported the occurrence of LA, anti- $\beta 2 \mathrm{GP} 1$ and antiphosphatidylethanolamine during the course of minocycline therapy $(123,124)$. The phenomenon of antibiotics-related aPL 
is arguable as it may be a consequence of the infectious process itself.

Other drugs, including fluvastatin, propylthiouracil, carvedilol, adalimumab, infliximab, and thalidomide and chemical agents such as acrylamide and silicone are suspected as being associated with aPL production but there is only a limited number of studies available. At least 10 cases of aPL-mediated vasculitis and/or thrombotic manifestations were attributed to cocaine abuse (125-127). It was suggested that certain cocaine-related clinical presentations can be related to the toxic effect of adulterant levamisole (antihelminth agent) or their synergic action.

The exact mechanisms of the drug-induced autoimmune reactions are not definitely known. Several pharmacological agents, including procainamide, quinidine, valproic acid, and phenytoin inevitably destroy the integrity of phospholipid bilayer by passing through the cell membrane to reach their site of action (128). Membrane perturbations may be implicated in altered presentation of neo-antigens or cryptic epitopes resulting in the consequent autoimmune responses. Among others, individual acetylation status and hapten-like characteristics of a particular drug may be considered as possible mechanisms for druginduced APL.

\section{OTHER ENVIRONMENTAL FACTORS}

Resident gut microbiota, together with other environmental factors such as nutritional status and stress, can play a crucial role in immune homeostasis (129). Numerous experiments carried out to understand whether dietary manipulations can result in a loss of self-tolerance have revealed compelling effects of daily calories, proteins or fat intake on the development of autoimmune diseases $(130,131)$. In particular, the diets containing omega-3-rich linseed oil as a fat source have demonstrated a reduction in the serum levels of aCL and antidsDNA antibodies in BALB/c mice with experimentally induced lupus (130). The fatty acid composition of cell membrane scan be influenced by the phospholipids ingested. Alterations of membrane structure and fluidity, observed in response to dietary fats, might result in modulation of functional activities of macrophages, dendritic cells, or T lymphocytes (132). Another mechanism, attributed to the immunomodulatory effects of omega-3, is the reduction of eicosanoid synthesis, which is an important mediator regulating secretion of cytokines and inflammatory gene expression (133). In autoimmune and thrombosis-prone W/BF1 mice, feeding a calorie-restricted diet resulted in the reduction of aCL and anti-dsDNA and in protection against thrombogenesis (134). Mechanisms of protective effect of calorie restriction against autoimmunity remain debatable, though it appears that abrogation of free radical generation and inflammatory responses may be involved (135).

Several studies emphasized a possible association of low serum vitamin $\mathrm{D}$ levels and/or high frequency of vitamin $\mathrm{D}$ insufficiency with hypercoagulable state in APS patients (136). Besides, vitamin D may inhibit the anti- $\beta 2$ GPI-stimulated TF expression in human umbilical vein endothelial cells (HUVECs) has been shown (137). Vitamin D alone as well as in combination with low molecular weight heparin (LMWH) may exert an anti-inflammatory effect on aPL-stimulated trophoblasts (138). Thus, vitamin D supplements may warrant further investigation as a promising prophylactic agent for preventing aPL-related thrombotic and obstetric complications.

\section{MECHANISMS OF APL PRODUCTION}

A variety of mechanisms have been suggested to explain the origin of aPL. Production of aPL is a complex and largely unknown process, encompassing a multifactorial interaction of genetic susceptibility variants and environmental factors. Infectious agents may cause the development of aPL through antigen-dependent mechanisms such as molecular mimicry, or in antigen-independent manner such as breakdown of immune tolerance due to inflammation.

Currently molecular mimicry is considered to be as the most prevalent explanation for a frequent association of infections and aPL-related clinical manifestations and APS. Molecular mimicry represents a phenomenon of structure-and-function similarity between foreign and host antigens. As a result, the self-tolerance is compromised and the pathogen-specific immune response cross-reacts with self-antigens. There is a strong evidence for a significant homology between the bacterial and viral structures and peptides derived from $\beta 2 \mathrm{GPI}$, which contribute to the selection of cross-reactive $\mathrm{T}$ and $\mathrm{B}$ cells. The molecular-mimicry hypothesis was tested in several animal model experiments designed to evaluate the pathogenic potential of infectious agents bearing membrane proteins similar to the main immunogenic epitopes targeted by anti- $\beta 2 \mathrm{GPI}$ antibodies. Induction of aPL in animals by heterologous $\beta 2 \mathrm{GPI}$ alluded that autoimmune reaction may be elicited by the immune complexes formed by host PL and PL-binding proteins derived from common infectious agents (139). Biopanning procedures identified synthetic peptides with high homology to the different regions of $\beta 2 \mathrm{GPI}$, which, in in vivo and in vitro experiments, diminished endothelial cell activation, and adhesion properties of monocytes caused by patient-derived anti- $\beta 2$ GPI (140). This group further showed a significant rise of aCL and anti-32GPI in mice immunized with Haemophilus influenzae, Neisseria gonorrhoeae, Candida albicans, or tetanus toxoid, which share structural homology with one of selected hexapeptides (TLRVYK) (141). As a confirmation to the earlier reports, APSrelated clinical and serological manifestations were corroborated in naive mice passively infused with anti-TLRVYK antibodies from immunized mice (141). Similar results were obtained when mice were immunized with other synthetic peptides of bacterial or viral origin (adenovirus, CMV, Bacillus subtilis) that shared sequence and functional similarity with a 15 amino acid peptide "GDKV" in major phospholipid-binding region of $\beta 2$ GPI (139). Induction of aCL and anti- $\beta 2 \mathrm{GPI}$ in immunized mice supported the idea that certain viral and bacterial agents may trigger autoreactive aPL response via interaction of infection-derived PL-binding peptides with host $\beta 2 \mathrm{GPI}$. 


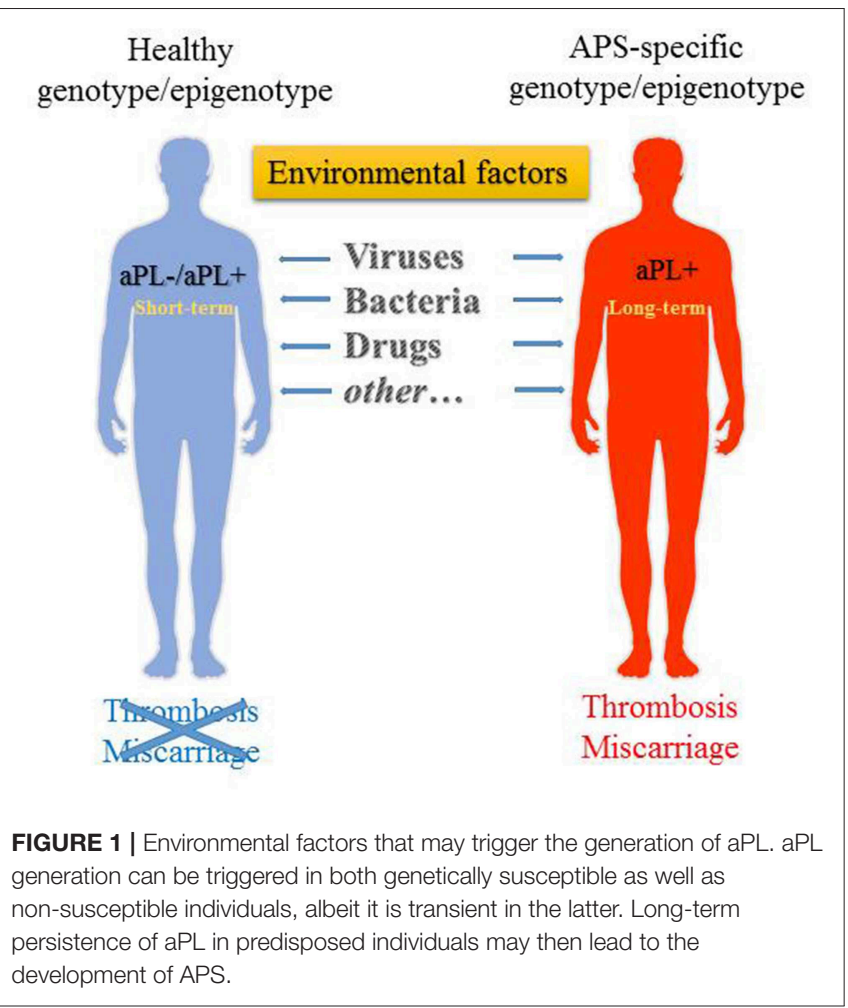

Infection(s) can cause conformational changes in $\beta 2 \mathrm{GPI}$ resulting in anti- $\beta 2$ GPI formation. Particularly, $\beta 2$ GPI was shown to interact with Streptococcus pyogenes surface protein $\mathrm{H}$, thereby exposing a cryptic epitope within domain I of $\beta 2 \mathrm{GPI}$ and triggering aPL response (142). Additionally, alteration of host antigenic determinants due to tissue injury and generation of neoepitopes may lead to molecular mimicry. Inflammation may play a role in modification of proteins, thus providing a source of neoepitopes that can be recognized by antibodies as a non-self. In the context of innate immune activation and a proinflammatory environment, interaction of $\beta 2 \mathrm{GPI}$ with anionic PL may result in the presentation of novel $\mathrm{T}$ cell epitopes, which are not observed in non-autoimmune individuals (143) and which appear as a result of modulation of presentation pathways (144). Among inflammatory cascades, oxidative stress is a key mechanism, which affects post-translational modification of proteins and/or alters membrane bilayers via lipid peroxidation (145). In addition, reactive species may enhance immunogenicity of $\beta 2 \mathrm{GPI}$. Elevated levels of circulating complexes, which are formed by oxidatively modified low density lipoproteins (oxLDL) and $\beta 2 \mathrm{GPI}$ (oxLDL/ $\beta 2 \mathrm{GPI}$ ) and recognized by anti- $\beta 2 \mathrm{GPI}$, were found to be associated with the increased risk of arterial thrombosis in APS and SLE patients (146).

In addition to the infection-induced $\beta 2 \mathrm{GPI}$ immunogenicity, certain conformational changes may lead to the exposure of the major B-cell binding site on domain I and of the major T-cell binding site on domain $\mathrm{V}$ that are required for aPL response (147). Each of the five $\beta 2 \mathrm{GPI}$ domains has been implicated in interaction with antibodies. The high immunogenicity and pathogenicity of antibodies with reactivity against DI of $\beta 2 \mathrm{GPI}$, however, is a newly recognized circumstance. It is thought that $\beta 2 \mathrm{GPI}$ in the serum is present predominantly in a "closed" circular conformation, in which the interaction of domain I with domain V prevents the exposure of the G39-R43 epitope. Upon the conformational change, induced by the interaction of $\beta 2$ GPI with anionic surfaces ("open" conformation), domain I opens up thus exposing a hidden epitope and triggering the formation of autoantibodies (148). Multiple epidemiological studies have demonstrated that antibodies against DI correlate with a substantially increased risk of thrombosis and, to a lesser extent, of pregnancy complications (149-151). This is especially relevant for the patients with a triple aPL positivity, that confers the highest risk for thrombotic events and more severe forms of APS (152-154). One of the mechanisms responsible for the increased thrombosis rates is an anti-D1-mediated increase in monocytic TF expression (our unpublished data). A very recent study challenged the pathogenic value of antibodies to domain 1 or $4 / 5$ of $\beta 2$ GPI in terms of risk stratification of APSrelated complications in-vitro. Potent procoagulant properties of anti-D1 were demonstrated in LPS-primed rats, while antiD5, similarly to negative control, was unable to promote clot formation (155). Despite this, there is still a controversy on whether the predictive power of classic aPL tests will benefit from anti-D1 screening (154) or not (153).

Anionic compounds with the ability to bind $\beta 2$ GPI appeared to be an interesting potential player in the pathogenic loop that supports continuous generation of anti- $\beta 2$ GPI in APS (144). The model proposed suggests that the Fc $\gamma \mathrm{RI}$-mediated uptake of $\beta 2 \mathrm{GPI} /$ anti- $\beta 2 \mathrm{GPI} /$ anionic surface complexes by macrophages results in recognition and presentation of the $\beta 2$ GPI cryptic determinants. A subsequent activation of $\beta 2$ GPI-reactive CD4+ $\mathrm{T}$ cells triggers anti- $\beta 2 \mathrm{GPI}$ production by $\mathrm{B}$ cells thus establishing a self-sustained loop (144). Under physiological conditions, systemic oxLDL, which are phospholipids expressed on activated platelets or presented on apoptotic bodies, may potentially act as a source of anionic substrates that form stable complexes with $\beta 2 \mathrm{GPI}$ to drive aPL response via the mechanism described above. In a focused review by Andreoli and coworkers, pathogenic interplay between aPL and apoptotic processes was emphasized (156). The authors pointed out that apoptotic cells may act as immunogenic factors capable of triggering the aPL response. On the other hand, the persistent exposure of aPL target by dying cells may promote autoimmunity through the maintenance of inflammation, especially in the settings with the increased IFN signature (156).

Notwithstanding of the numerous mechanisms proposed, it is not clear how aPL antibodies induce thrombosis and obstetric complications. It was suggested that the sustained aPL titers and procoagulatory state "first hit" precipitate thrombotic events only in the presence of inflammatory "second hit" (157). Factors such as trauma, vascular injury, surgery, pregnancy, age, hypertension, diabetes, obesity, and infection may also potentiate thrombus formation $(158,159)$.

The etiology of APS is attributed to the interplay between genetic and environmental insults. Nevertheless, the impact of environment on disease risk is difficult to evaluate and the 
TABLE 1 | Bacterial, viral, and parasitic agents linked to the aPL production and clinical manifestation.

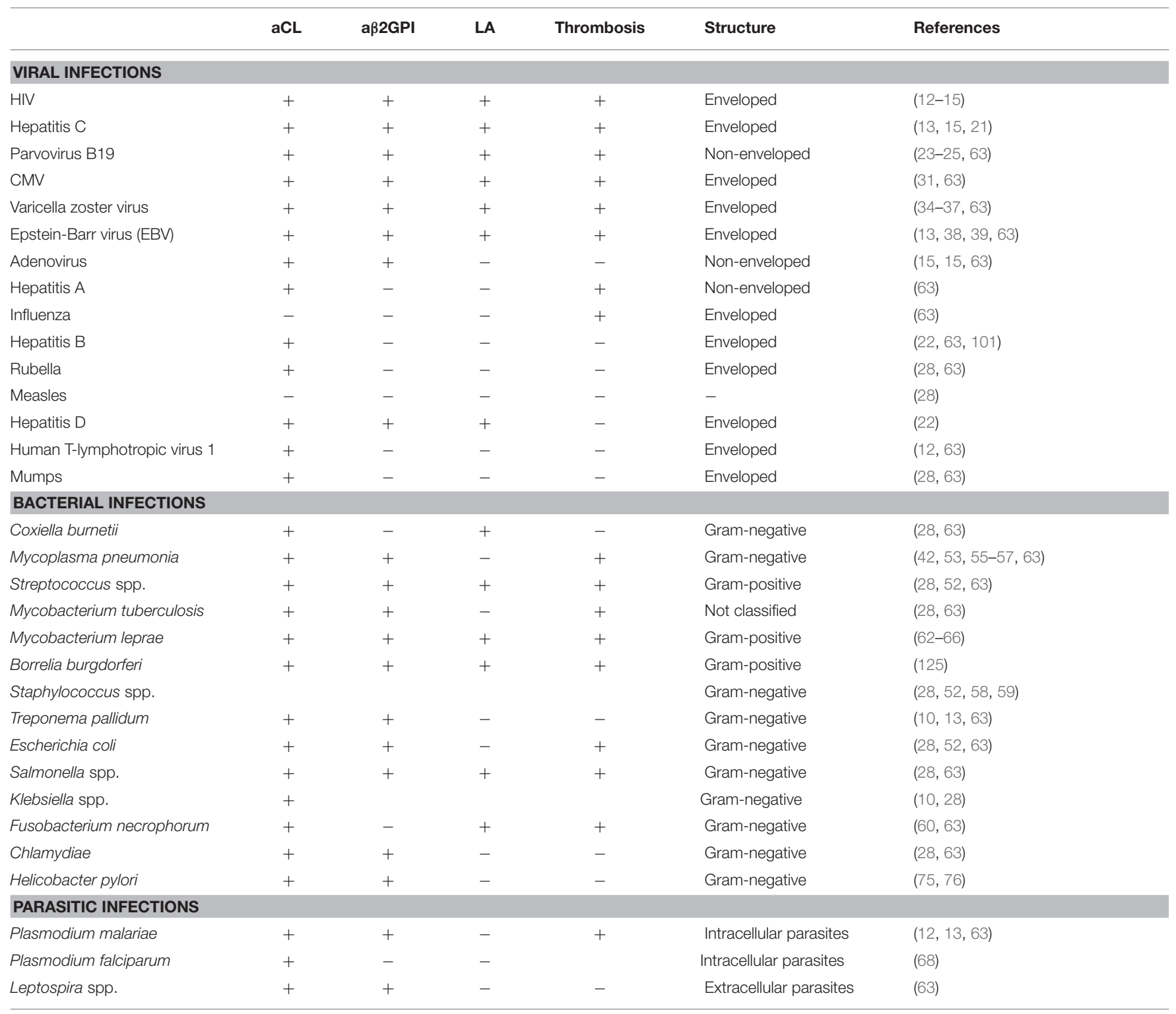

mechanisms involved remain pressing and enigmatic. Evidences accumulated over decades indicate that gene-environment interactions, mediated at the epigenetic level, may trigger autoimmune processes (160). Epigenetic alterations may regulate CD4, CD8 and B cell functions and appears to drive maturation of the high-affinity antibody response $(161,162)$. It is therefore intriguing to investigate the influence of particular environment factors on epigenetic landscape and following aPL response.

Our review includes the wide range of publications describing environmentally-triggered aPL generation including research papers, case reports, case-control studies, reviews, and clinical, epidemiological, population-based and big-cohort studies. Despite this, we are aware that the data in this review might be limited for several reasons. The first is the biased/heterogeneous or limited data of the relevant reviewed studies. The second limitation concerns the laboratory procedures for aPL detection, which still lack of standardization and interpretation strategies and may vary among laboratories. The possible variation arising from non-uniformity of results interpretation were not considered here.

\section{CONCLUSION}

In summary, the environmental triggers such as bacteria, viruses, commensal bacteria, vaccines, drugs, and other factors are potentially capable of inducing a variety of aPL and causing APS through a wide range of mechanisms in genetically susceptible individuals (Figure 1). These factors are also specified in Table 1. A most compelling evidence supporting the role of 
environmental factors in induction of aPL is largely obtained from the epidemiological studies. The presence of aPL in healthy individuals points to the normal physiological role played by aPL. The post-infection increase of aPL is usually transient, and it is not accompanied by the manifestations of APS such as thrombosis. The main question remains, however, why in a genetically susceptible host the increase of aPL in response to the environmental stimuli is not resolved and results in the transition from low-affinity to high-affinity autoantibodies, with the increased pathogenic potential of aPL. Presently our understanding of mechanisms of inflammation resolution and self-tolerance is rather limited and cannot explain why in a subset of population initial adaptive immune response against foreign antigens is rerouted against self-antigens.

\section{REFERENCES}

1. Schreiber K, Sciascia S, de Groot PG, Devreese K, Jacobsen S, Ruiz-Irastorza G, et al. Antiphospholipid syndrome. Nat Rev Dis Primers. (2018) 11:17103. doi: $10.1038 / \mathrm{nrdp} .2017 .103$

2. Miyakis S, Lockshin MD, Atsumi I, Branch DW, Brey RL, Cervera R, et al. International concensus statement on an update of the classification criteria for definite antiphospholipid syndrome (APS). J Thromb Haemost. (2006) 4:295-306. doi: 10.1111/j.1538-7836.2006.01753.x

3. Willis R, Pierangeli SS. Pathophysiology of the antiphospholipid antibody syndrome. Auto Immun Highlights. (2011) 2:35-52. doi: 10.1007/s13317-011-0017-9

4. von Landenberg P, Doring Y, Modrow S, Lackner KJ. Are antiphospholipid antibodies an essential requirement for an effective immune response to infections? Ann N Y Acad Sci. (2007) 1108:578-83. doi: 10.1196/annals. 1422.060

5. Salmon JE, de Groot PG. Pathogenic role of antiphospholipid antibodies. Lupus. (2008) 17:405-11. doi: 10.1177/0961203308090025

6. Pericleous C, Ruiz-Limón P, Romay-Penabad Z, Marín AC, Garza-Garcia A, Murfitt L, et al. Proof-of-concept study demonstrating the pathogenicity of affinity-purified IgG antibodies directed to domain I of $\beta 2$-glycoprotein I in a mouse model of anti-phospholipid antibody-induced thrombosis. Rheumatology. (2015) 54:722-7. doi: 10.1093/rheumatology/keu360

7. Giannakopoulos B, Passam F, Rahgozar S, Krilis SA. Current concepts on the pathogenesis of the antiphospholipid syndrome. Blood. (2007) 109:422-30. doi: 10.1182/blood-2006-04-001206

8. Nakanishi T, Suzuki N, Kuragano T, Nagasawa Y, Hasuike Y. Current topics in therapeutic plasmapheresis. Clin Exp Nephrol. (2014) 18:41-9. doi: 10.1007/s10157-013-0838-0

9. Martirosyan A, Petrek M, Kishore A, Manukyan G. The immunomodulatory effects of therapeutic plasma exchange on monocytes in Antiphospholipid syndrome. Exp Ther Med. (2016) 12:1189-95. doi: 10.3892/etm.2016.3441

10. McNally T, Purdy G, Mackie IJ, Machin SJ, Isenberg DA. The use of an anti-beta2-glycoprotein-I assay for discrimination between anticardiolipin antibodies associated with infection and increased risk of thrombosis. $\mathrm{Br} \mathrm{J}$ Haematol. (1995) 91:471-3. doi: 10.1111/j.1365-2141.1995.tb05324.x

11. Canoso RT, Zon LI, Groopman JE. Anticardiolipin antibodies associated with HTLV-III infection. Br J Haematol. (1987) 65:495-8. doi: 10.1111/j.1365-2141.1987.tb04157.x

12. Asherson RA, Cervera R. Antiphospholipid antibodies and infections. Ann Rheum Dis. (2003) 62:388-93. doi: 10.1136/ard.62.5.388

13. Sene D, Piette JC, Cacoub P. Antiphospholipid antibodies, antiphospholipid syndrome and infections. Autoimmune Rev. (2008) 7:272-7. doi: 10.1016/j.autrev.2007.10.001

14. Galrão L, Brites C, Atta ML, Atta A, Lima I, Gonzalez F, et al. Antiphospholipid antibodies in HIV-positive patients. Clin Rheumatol. (2007) 26:1825-30. doi: 10.1007/s10067-007-0581-6

15. Uthman IW, Gharavi AE. Viral infections and antiphospholipid antibodies. Semin Arthritis Rheum. (2002) 31:256-63. doi: 10.1053/sarh.2002.28303
Does it involve compromised innate immunity mechanisms ensuing continuous activation via the DAMP signaling? Or is adaptive immune response in the later stages involved that prevents clonal selection of $\mathrm{T}$ and $\mathrm{B}$ cells producing selfantibodies? Uncovering the mechanisms behind the generation of heterogeneous aPL that contribute to the development of APS will help to design the strategies for treatment and prevention of this disease.

\section{AUTHOR CONTRIBUTIONS}

All authors listed have made a substantial, direct and intellectual contribution to the work, and approved it for publication.

16. Guglielmone H, Vitozzi S, Elbarcha O, Fernandez E. Cofactor dependence and isotype distribution of anticardiolipin antibodies in viral infections. Ann Rheum Dis. (2001) 60:500-4. doi: 10.1136/ard.60. 5.500

17. Gharavi AE, Sammaritano LR, Wen J, Miyawaki N, Morse JH, Zarrabi MH, et al. Characteristics of human immunodeficiency virus and chlorpromazine induced antiphospholipid antibodies: effect of beta 2 glycoprotein I on binding to phospholipid. J Rheumatol. (1994) 21:94-9.

18. Petrovas C, Vlachoyiannopoulos PG, Kordossis T, Moutsopoulos HM. Anti-phospholipid antibodies in HIV infection and SLE with or without anti-phospholipid syndrome: comparisons of phospholipid specificity, avidity and reactivity with beta2-GPI. J Autoimmun. (1999) 13:347-55. doi: 10.1006/jaut.1999.0324

19. Bibas M, Biava G, Antinori A. HIV-associated venous thromboembolism. Mediterr J Hematol Infect Dis. (2011) 3:e2011030. doi: 10.4084/mjhid.2011.030

20. Giordano P, Galli M, Del Vecchio GC, Altomare M, Norbis F, et al. Lupus anticoagulant, anticardiolipin antibodies and hepatitis C virus infection in thalassaemia. Br J Haematol. (1998) 102:903-6. doi: 10.1046/j.1365-2141.1998.00853.x

21. Ramos-Casals M, Cervera R, Lagrutta M, Medina F, García-Carrasco $\mathrm{M}$, de la Red $\mathrm{G}$, et al. Clinical features related to antiphospholipid syndrome in patients with chronic viral infections (hepatitis $\mathrm{C}$ virus/HIV infection): description of 82 cases. Clin Infect Dis. (2004) 38:1009-16. doi: $10.1086 / 382537$

22. Elefsiniotis IS, Diamantis ID, Dourakis SP, Kafiri G, Pantazis K, Mavrogiannis C. Anticardiolipin antibodies in chronic hepatitis B and chronic hepatitis D infection, and hepatitis B-related hepatocellular carcinoma. Relationship with portal vein thrombosis. Eur J Gastroenterol Hepatol. (2003) 15:721-6. doi: 10.1097/01.meg.0000059140. 68845.74

23. Kerr JR. The role of parvovirus B19 in the pathogenesis of autoimmunity and autoimmune disease. J Clin Pathol. (2016) 69:279-91. doi: 10.1136/jclinpath-2015-203455

24. von Landenberg P, Lehmann HW, Knöll A, Dorsch S, Modrow S. Antiphospholipid antibodies in pediatric and adult patients with rheumatic disease are associated with parvovirus B19 infection. Arthritis Rheum. (2003) 48:1939-47. doi: 10.1002/art.11038

25. Loizou S, Cazabon JK, Walport MJ, Tait D, So AK. Similarities of specificity and cofactor dependence in serum antiphospholipid antibodies from patients with human parvovirus B19 infection and from those with systemic lupus erythematosus. Arthritis Rheum. (1997) 40:103-8. doi: 10.1002/art.1780400115

26. Asano Y, Sarukawa M, Idezuki T, Harada S, Kaji K, Nakasu I, et al. Multiple small pulmonary emboli associated with transient antiphospholipid syndrome in human Parvovirus B19 infection. Clin Rheumatol. (2006) 25:585-7. doi: 10.1007/s10067-005-0032-1

27. Kranidiotis G, Efstratiadis E, Kapsalakis G, Loizos G, Bilis A, Melidonis A. Splenic infarcts as a rare manifestation of parvovirus 
B19 infection. ID Cases. (2016) 4:62-4. doi: 10.1016/j.idcr.2016. 04.003

28. Abdel-Wahab N, Lopez-Olivo MA, Pinto-Patarroyo GP, SuarezAlmazor ME. Systematic review of case reports of antiphospholipid syndrome following infection. Lupus. (2016) 25:1520-31. doi: 10.1177/0961203316640912

29. Williams MV, Cox B, Ariza ME. Herpesviruses dUTPases: a new family of Pathogen-Associated Molecular Pattern (PAMP) proteins with implications for human disease. Pathogens. (2016) 6:2. doi: 10.3390/pathogens6010002

30. De Carolis S, Tabacco S, Rizzo F, Perrone G, Garufi C, Botta A, et al. Association between false-positive TORCH and antiphospholipid antibodies in healthy pregnant women. Lupus. (2018). 27:841-6. doi: 10.1177/0961203317741564

31. Justo D, Finn T, Atzmony L, Guy N, Steinvil A. Thrombosis associated with acute cytomegalovirus infection: a meta-analysis. Eur J Intern Med. (2011) 22:195-9. doi: 10.1016/j.ejim.2010.11.006

32. Rahbar A, Söderberg-Nauclér C. Human cytomegalovirus infection of endothelial cells triggers platelet adhesion and aggregation. J Virol. (2005) 79:2211-20. doi: 10.1128/JVI.79.4.2211-2220.2005

33. Squizzato A, Gerdes VE, Büller HR. Effects of human cytomegalovirus infection on the coagulation system. Thromb Haemost. (2005) 93:403-10. doi: 10.1160/TH04-08-0523

34. Josephson C, Nuss R, Jacobson L, Hacker MR, Murphy J, Weinberg A, et al. The varicella-autoantibody syndrome. Pediatr Res. (2001) 50:345-52. doi: 10.1203/00006450-200109000-00009

35. Viseux V, Darnige L, Carmi E, Chaby G, Poulain JF, Cevallos $\mathrm{R}$, et al. Pulmonary embolism and transitory anti-beta2-GPI antibodies in an adult with chicken pox. Lupus. (2000) 9:558-60. doi: 10.1177/096120330000900716

36. Losurdo G, Giacchino R, Castagnola E, Gattorno M, Costabel S, Rossi A, et al. Cerebrovascular disease and varicella in children. Brain Dev. (2006) 28:366-70. doi: 10.1016/j.braindev.2005.11.002

37. Frontino G, Passoni A, Piscopo MA, Grechi E, Cammarata B, Pozzobon G. Bilateral cavo-ilio-femoral thrombosis in an adolescent with transient antiphospholipid antibodies and factor $\mathrm{V}$ heterozygous mutation: a case report. Cases J. (2009) 2:6830. doi: 10.4076/1757-1626-2-6830

38. Zandman-Goddard G, Berkun Y, Barzilai O, Boaz M, Blank M, Ram M, et al. Exposure to Epstein-Barr virus infection is associated with mild systemic lupus erythematosus disease. Ann N Y Acad Sci. (2009) 1173:65863. doi: 10.1111/j.1749-6632.2009.04754.x

39. Ogawa J, Koike R, Sugihara T, Hagiyama H, Nishio J, Kohsaka H, et al. [An autopsied case of chronic active Epstein-Barr virus infection complicated in systemic lupus erythematosus and antiphospholipid antibody syndrome]. Nihon Rinsho Meneki Gakkai Kaishi. (2002) 25:458-65. doi: $10.2177 /$ jsci. 25.458

40. Delbos V, Abgueguen P, Chennebault JM, Fanello S, Pichard E. Acute cytomegalovirus infection and venous thrombosis: role of antiphospholipid antibodies. J Infect. (2008) 54:e47-50. doi: 10.1016/j.jinf.2006.03.031

41. Kratz C, Mauz-Körholz C, Kruck H, Körholz D, Göbel U. Detection of antiphospholipid antibodies in children and adolescents. Pediatr Hematol Oncol. (1998) 15:325-32. doi: 10.3109/08880019809014016

42. Shimizu T, Ishiguro A, Takayanagi T, Matsui T, Tonegawa N, Maekawa $\mathrm{T}$, et al. [A case of lupus anticoagulant hypoprothrombinemia syndrome following adenovirus gastroenteritis and mycoplasma pneumonia]. Nihon Rinsho Meneki Gakkai Kaishi. (2014) 37:55-60. doi: 10.2177/jsci.37.55

43. Mazzon M, Mercer J. Lipid interactions during virus entry and infection. Cell Microbiol. (2014) 16:1493-502. doi: 10.1111/cmi.12340

44. Lorizate M, Sachsenheimer T, Glass B, Habermann A, Gerl MJ, Krausslich HG, et al. Comparative lipidomics analysis of HIV-1 particles and their producer cell membrane in different cell lines. Cell Microbiol. (2013) 15:292304. doi: $10.1111 / \mathrm{cmi} .12101$

45. Chan R, Uchil PD, Jin J, Shui G, Ott DE, Mothes W, et al. Retroviruses human immunodeficiency virus and murine leukemia virus are enriched in phosphoinositides. J Virol. (2008) 82:11228-38. doi: 10.1128/JVI. 00981-08

46. de Armas-Rillo L, Valera MS, Marrero-Hernández S, Valenzuela-Fernández A. Membrane dynamics associated with viral infection. Rev Med Virol. (2016) 26:146-60. doi: $10.1002 / \mathrm{rmv} .1872$
47. Haynes BF, Fleming J, St. Clair EW, Katinger H, Stiegler G, Kunert R, et al. Cardiolipin polyspecific autoreactivity in two broadly neutralizing HIV-1 antibodies. Science. (2005) 308:1906-8. doi: 10.1126/science.1111781

48. Martinez V, Diemert MC, Braibant M, Potard V, Charuel JL, Barin F, et al. Anticardiolipin antibodies in HIV infection are independently associated with antibodies to the membrane proximal external region of gp41 and with cell-associated HIV DNA and immune activation. Clin Infect Dis. (2009) 48:123-32. doi: 10.1086/595013

49. Diaz JS, Octavio JG, Fernandez-Guerrero ML. Antiphospholipid syndrome and acute HIV infection. Emerg Infect Dis. (2010) 16:360-1. doi: 10.3201/eid1602.090728

50. Martirosyan A, Petrek M, Navratilova Z, Blbulyan A, Boyajyan A, Manukyan G. Differential regulation of proinflammatory mediators following LPS- and ATP-induced activation of monocytes from patients with antiphospholipid syndrome. Biomed Res Int. (2015) 2015:292851. doi: 10.1155/2015/292851

51. Arleevskaya MI, Manukyan G, Inoue R, Aminov R. Editorial: microbial and environmental factors in autoimmune and inflammatory diseases. Front Immunol. (2017) 8:243. doi: 10.3389/fimmu.2017.00243

52. Cervera R, Asherson RA, Acevedo ML, Gómez-Puerta JA, Espinosa G, De La Red G, et al. Antiphospholipid syndrome associated with infections: clinical and microbiological characteristics of 100 patients. Ann Rheum Dis. (2004) 63:1312-7. doi: 10.1136/ard.2003.014175

53. Snowden N, Wilson PB, Longson M, Pumphrey RS. Antiphospholipid antibodies and Mycoplasma pneumoniae infection. Postgrad Med J. (1990) 66:356-62. doi: 10.1136/pgmj.66.775.356

54. Ardiles L, Ramirez P, Moya P, Caorsi I, Mezzano S. Anticardiolipin antibodies in acute poststreptococcal glomerulonephritis and streptococcal impetigo. Nephron. (1999) 83:47-52. doi: 10.1159/000045472

55. Espinosa G, Santos E, Cervera R, Piette JC, de la Red G, Gil V, et al. Adrenal involvement in the antiphospholipid syndrome: clinical and immunologic characteristics of 86 patients. Medicine. (2003) 82:106-18. doi: 10.1097/00005792-200303000-00005

56. Bakshi M, Khemani C, Vishwanathan V, Anand RK, Khubchandani RP. Mycoplasma pneumonia with antiphospholipid antibodies and a cardiac thrombus. Lupus. (2006) 15:105-6. doi: 10.1191/0961203306lu2258cr

57. Graw-Panzer KD, Verma S, Rao S, Miller ST, Lee H. Venous thrombosis and pulmonary embolism in a child with pneumonia due to Mycoplasma pneumoniae. J Natl Med Assoc. (2009) 101:956-8. doi: 10.1016/S0027-9684(15)31045-2

58. Witmer CM, Steenhoff AP, Shah SS, Raffini LJ. Mycoplasma pneumoniae, splenic infarct, and transient antiphospholipid antibodies: a new association? Pediatrics. (2007) 119:e292-5. doi: 10.1542/peds.2006-1340

59. Harada M, Nishi Y, Tamura S, Iba Y, Abe K, Yanbe Y, et al. [Infective endocarditis with a huge mitral vegetation related to atopic dermatitis and high serum level of infection-related antiphospholipid antibody: a case report]. J Cardiol. (2003) 42:135-40.

60. Goldenberg NA, Knapp-Clevenger R, Hays T, Manco-Johnson MJ. Lemierre's and Lemierre's-like syndromes in children: survival and thromboembolic outcomes. Pediatrics. (2005) 116:e543-8. doi: 10.1542/peds.2005-0433

61. Johannesen KM, Bodtger U. Lemierre's syndrome: current perspectives on diagnosis and management. Infect Drug Resist. (2016) 9:221-7. doi: 10.2147/IDR.S95050

62. Forastiero RR, Martinuzzo ME, de Larrañaga GF. Circulating levels of tissue factor and proinflammatory cytokines in patients with primary antiphospholipid syndrome or leprosy related antiphospholipid antibodies. Lupus. (2005) 14:129-36. doi: 10.1191/0961203305lu2048oa

63. Avcin T, Toplak N. Antiphospholipid antibodies in response to infection. Curr Rheumatol Rep. (2007) 9:212-8. doi: 10.1007/s11926-007-0034-x

64. Fiallo P, Travaglino C, Nunzi E, Cardo PP. Beta 2-Glycoprotein I-dependence of anticardiolipin antibodies in multibacillary leprosy patients. Lepr Rev. (1998) 69:376-81. doi: 10.5935/0305-7518.19980038

65. de Larrañaga GF, Forastiero RR, Martinuzzo ME, Carreras LO, Tsariktsian G, Sturno MM, et al. High prevalence of antiphospholipid antibodies in leprosy: evaluation of antigen reactivity. Lupus. (2000) 9:594-600. doi: $10.1191 / 096120300678828712$

66. Levy RA, de Meis E, Pierangeli S. An adapted ELISA method for differentiating pathogenic from non-pathogenic aPL by a beta 2 glycoprotein 
I dependency anticardiolipin assay. Thromb Res. (2004) 114:573-7. doi: 10.1016/j.thromres.2004.06.032

67. Ordoñez C, Savage HP, Tarajia M, Rivera R, Weeks-Galindo C, Sambrano D, et al. Both B-1a and B-1b cells exposed to Mycobacterium tuberculosis lipids differentiate into IgM antibody-secreting cells. Immunology. (2018) 154:613-23. doi: 10.1111/imm.12909

68. Adebajo AO, Charles P, Maini RN, Hazleman BL. Autoantibodies in malaria, tuberculosis and hepatitis B in a west African population. Clin Exp Immunol. (1993) 92:73-6. doi: 10.1111/j.1365-2249.1993.tb05950.x

69. Elkayam O, Caspi D, Lidgi M, Segal R. Auto-antibody profiles in patients with active pulmonary tuberculosis. Int J Tuberc Lung Dis. (2007) 11:306-10.

70. Shen CY, Hsieh SC, Yu CL, Wang JY, Lee LN, Yu CJ. Autoantibody prevalence in active tuberculosis: reactive or pathognomonic? BMJ Open. (2013) 26:7.doi: 10.1136/bmjopen-2013-002665

71. Elkayam O, Bendayan D, Segal R, Shapira Y, Gilburd B, Reuter S, et al. The effect of anti-tuberculosis treatment on levels of anti-phospholipid and anti-neutrophil cytoplasmatic antibodies in patients with active tuberculosis. Rheumatol Int. (2013) 33:949-53. doi: 10.1007/s00296-012-2487-0

72. Goodridge A, Cueva C, Lahiff M, Muzanye G, Johnson JL, Nahid P, et al. Anti-phospholipid antibody levels as biomarker for monitoring tuberculosis treatment response. Tuberculosis. 92:243-7. doi: 10.1016/j.tube.2012.02.004

73. Backert S, Neddermann M, Maubach G, Naumann M. Pathogenesis of Helicobacter pylori infection. Helicobacter Suppl. (2016) 1:19-25. doi: 10.1111/hel.12335

74. Smyk DS, Koutsoumpas AL, Mytilinaiou MG, Rigopoulou EI, Sakkas LI, Bogdanos DP. Helicobacter pylori and autoimmune disease: cause or bystander. World J Gastroenterol. (2014) 20:613-29. doi: 10.3748/wjg.v20.i3.613

75. Ram M, Barzilai O, Shapira Y, Anaya JM, Tincani A, Stojanovich L, et al. Helicobacter pylori serology in autoimmune diseases-fact or fiction? Clin Chem Lab Med. (2013) 51:1075-82. doi: 10.1515/cclm-2012-0477

76. Sarici SU, Gursel O, Kurekci E, Kesik V, Atay A, Okutan V, et al. Anticardiolipin antibodies in children with Helicobacter pylori infection. Helicobacter. (2015) 20:418-21. doi: 10.1111/hel.12226

77. Mankaï A, Layouni S, Ghedira I. Anti Saccharomyces cerevisiae antibodies in patients with anti- $\beta 2$ glycoprotein I antibodies. J Clin Lab Anal. (2016) 30:818-22. doi: 10.1002/jcla.21942

78. Sipeki N, Davida L, Palyu E, Altorjay I, Harsfalvi J, Szalmas PA, et al. Prevalence, significance and predictive value of antiphospholipid antibodies in Crohn's disease. World J Gastroenterol. (2015) 21:6952-64. doi: 10.3748/wjg.v21.i22.6952

79. Mankaï A, Sakly W, Thabet Y, Achour A, Manoubi W, Ghedira I. Anti-Saccharomyces cerevisiae antibodies in patients with systemic lupus erythematosus. Rheumatol Int. (2013) 33:665-9. doi: 10.1007/s00296-012-2431-3

80. Dai H, Li Z, Zhang Y, Lv P, Gao XM. Elevated levels of serum IgA against Saccharomyces cerevisiae mannan in patients with rheumatoid arthritis. Cell Mol Immunol. (2009) 6:361-6. doi: 10.1038/cmi.2009.47

81. Krause I, Blank M, Cervera R, Font J, Matthias T, Pfeiffer S, et al. Crossreactive epitopes on beta2-glycoprotein-I and Saccharomyces cerevisiae in patients with the antiphospholipid syndrome. Ann N Y Acad Sci. (2007) 1108:481-8. doi: 10.1196/annals.1422.051

82. Israeli E, Grotto I, Gilburd B, Balicer RD, Goldin E, Wiik A, et al. Anti-Saccharomyces cerevisiae and antineutrophil cytoplasmic antibodies as predictors of inflammatory bowel disease. Gut. (2005) 54:1232-6. doi: $10.1136 /$ gut.2004.060228

83. Amital H, Gilburd B, Shoenfeld Y. Probiotic supplementation with Lactobacillus casei (Actimel) induces a Th1 response in an animal model of antiphospholipid syndrome. Ann N Y Acad Sci. (2007) 1110:661-9. doi: 10.1196/annals. 1423.069

84. Ruff WE, Vieira SM, Kriegel MA. The role of the gut microbiota in the pathogenesis of antiphospholipid syndrome. Curr Rheumatol Rep. (2015) 17:472. doi: 10.1007/s11926-014-0472-1

85. Aguiar CL, Ruff W, Goodman A, Erkan D, Kriegel M. Cardiolipin-producing candidate commensals in the gut microbiome of antiphospholipid syndrome patients. Arthritis Rheumatol. (2016) 68 (Suppl. 10).

86. Furusawa Y, Obata Y, Fukuda S, Endo TA, Nakato G, Takahashi D, et al. Commensal microbe-derived butyrate induces the differentiation of colonic regulatory T cells. Nature. (2013) 19:446-50. doi: 10.1038/nature 12721

87. Vieira SM, Yu A, Pagovich OE, Tiniakou E, Sterpka J, Kriegel MA. Depletion of the gut microbiota prevents $\beta 2$-glycoprotein I antibody production and mortality in a model of antiphospholipid syndrome. Arthritis Rheum. (2013) S1-1331.

88. Kagan VE, Tyurina YY, Tyurin VA, Mohammadyani D, Angeli JP, Baranov SV, et al. Cardiolipin signaling mechanisms: collapse of asymmetry and oxidation. Antioxid Redox Signal. (2015) 22:1667-80. doi: $10.1089 /$ ars.2014.6219

89. Lewis RN, Mc Elhaney RN. The physicochemical properties of cardiolipin bilayers and cardiolipin-containing lipid membranes. Biochim Biophys Acta. (2009) 1788:2069-79. doi: 10.1016/j.bbamem.2009.03.014

90. Epand RM, Epand RF. Lipid domains in bacterial membranes and the action of antimicrobial agents. Biochim Biophys Acta. (2009) 1788:289-94. doi: 10.1016/j.bbamem.2008.08.023

91. Subang R, Levine JS, Janoff AS, Davidson SM, Taraschi TF, Koike T, et al. Phospholipid-bound beta 2-glycoprotein I induces the production of anti-phospholipid antibodies. J Autoimmun. (2000) 15:21-32. doi: $10.1006 /$ jaut.2000.0382

92. Watanabe T, Onda H. Henoch-Schönleinpurpura with antiphospholipid antibodies following an influenza vaccination. Pediatr Nephrol. (2001) 16:458-9. doi: 10.1007/s004670100569

93. Mormile R, D’Alterio V, Treccagnoli G, Sorrentino P. HenochSchonleinpurpura with antiphospholipid antibodies after influenza vaccination: how fearful is it in children? Vaccine. (2004) 23:567-8. doi: $10.1016 /$ j.vaccine.2004.07.029

94. Abu-Shakra M, Press J, Varsano N, Levy V, Mendelson E, Sukenik S, et al. Specific antibody response after influenza immunization in systemic lupus erythematosus. J Rheumatol. (2002) 29:2555-7.

95. Tarján P, Sipka S, Lakos G, Kiss E, Ujj G, Szegedi G. Influenza vaccination and the production of anti-phospholipid antibodies in patients with systemic lupus erythematosus. Scand J Rheumatol. (2006) 35:241-3. doi: 10.1080/03009740500474552

96. Toplak N, Kveder T, Trampuš-Bakija A, Subelj V, Cučnik S, Avčin T. Autoimmune response following annual influenza vaccination in 92 apparently healthy adults. Autoimmun Rev. (2008) 8:134-8. doi: 10.1016/j.autrev.2008.07.008

97. Vista ES, Crowe SR, Thompson LF, Air GM, Robertson JM, Guthridge $\mathrm{JM}$, et al. Influenza vaccination can induce new-onset anticardiolipins but not $\beta 2$-glycoprotein-I antibodies among patients with systemic lupus erythematosus. Lupus. (2012) 21:168-74. doi: 10.1177/09612033114 29554

98. de Medeiros DM, Silva CA, Bueno C, Ribeiro AC, Viana Vdos S, Carvalho JF, et al. Pandemic influenza immunization in primary antiphospholipid syndrome (PAPS): a trigger to thrombosis and autoantibody production? Lupus. (2014) 23:1412-6. doi: 10.1177/0961203314540351

99. Vainer-Mossel ED, Mekori YA, Mor A. Ischemic stroke in a patient with lupus following influenza vaccination: a questionable association. Isr Med Assoc J. (2009) 11:186-7.

100. Korematsu S, Miyahara H, Kakita A, Izumi T. Elevated serum anti-phosphatidylcholineIgG antibodies in patients with influenza vaccination-associated optic neuritis. Vaccine. (2014) 32:6345-8. doi: 10.1016/j.vaccine.2014.09.053

101. Martinuc Porobic J, Avcin T, Bozic B, Kuhar M, Cucnik S, Zupancic $\mathrm{M}$, et al. Anti-phospholipid antibodies following vaccination with recombinant hepatitis B vaccine. Clin Exp Immunol. (2005) 142:377-80. doi: 10.1111/j.1365-2249.2005.02923.x

102. Meyer A, Rotman-Pikielny P, Natour A, Levy Y. Antiphospholipid syndrome following a diphtheria-tetanus vaccination: coincidence vs. causality. Isr Med Assoc J. (2010) 12:638-9.

103. Bizjak M, Bruck O, Kanduc D, Praprotnik S, Shoenfeld Y. Vaccinations and secondary immune thrombocytopenia with antiphospholipid antibodies by human papillomavirus vaccine. Semin Hematol. (2016) 53 (Suppl. 1):S48-50. doi: 10.1053/j.seminhematol.2016.04.014

104. Dimitrijević L, Živković I, Stojanović M, Petrušić V, Živančevi C, Simonović S. Vaccine model of antiphospholipid syndrome induced by tetanus vaccine. Lupus. (2012) 21:195-202. doi: 10.1177/0961203311429816 
105. Zivkovic I, Petrusic V, Stojanovic M, Inic-Kanada A, Stojicevic I, Dimitrijevic L. Induction of decreased fecundity by tetanus toxoid hyper-immunization in C57BL/6 mice depends on the applied adjuvant. Innate Immun. (2012) 18:333-42. doi: 10.1177/1753425911407361

106. Blank M, Israeli E, Shoenfeld Y. When APS (Hughes syndrome) met the autoimmune/inflammatory syndrome induced by adjuvants (ASIA). Lupus. (2012) 21:711-4. doi: 10.1177/0961203312438115

107. Shoenfeld Y, Agmon-Levin N. 'ASIA'-autoimmune/inflammatory syndrome induced by adjuvants. J Autoimmun. (2011) 36:4-8. doi: 10.1016/j.jaut.2010.07.003

108. Hoffman BJ. Sensitivity to sufadiazine resembling acute disseminated lupus erythematosus. Arch Derm Syphilol. (1945) 51:190-2. doi: 10.1001/archderm.1945.01510210032007

109. Dlott JS, Roubey RA. Drug-induced lupus anticoagulants and antiphospholipid antibodies. Curr Rheumatol Rep. (2012) 14:71-8. doi: 10.1007/s11926-011-0227-1

110. Canoso RT, De Oliveira RM. Chlorpromazine-induced anticardiolipin antibodies and lupus anticoagulant: absence of thrombosis. Am J Hematol. (1988) 27:272-5. doi: 10.1002/ajh.2830270408

111. Triplett DA, Brandt JT, Musgrave KA, Orr CA. The relationship between lupus anticoagulants and antibodies to phospholipid. JAMA. (1988) 259:5504. doi: 10.1001/jama.1988.03720040042024

112. Kameda H, Mimori T, Kaburaki J, Fujii T, Takahashi T, Akaishi M, et al. Systemic sclerosis complicated by procainamide-induced lupus and antiphospholipid syndrome. Br J Rheumatol. (1998) 37:1236-9. doi: 10.1093/rheumatology/37.11.1236

113. Gastineau DA, Kazmier FJ, Nichols WL, Bowie EJ. Lupus anticoagulant: an analysis of the clinical and laboratory features of 219 cases. Am J Hematol. (1985) 19:265-75. doi: 10.1002/ajh.2830190308

114. Walker TS, Triplett DA, Javed N, Musgrave K. Evaluation of lupus anticoagulants: antiphospholipid antibodies, endothelium associated immunoglobulin, endothelial prostacyclin secretion, and antigenic protein $\mathrm{S}$ levels. Thromb Res. (1988) 51:267-81. doi: 10.1016/0049-3848(88)90104-1

115. Bird MR, O'Neill AI, Buchanan RR, Ibrahim KM, Des PJ. Lupus anticoagulant in the elderly may be associated with both quinine and quinidine usage. Pathology. (1995) 27:136-9. doi: 10.1080/00313029500169742

116. Rosa-Re D, García F, Gascon J, Angrill J, Cervera R. Quinine induced lupuslike syndrome and cardiolipin antibodies. Ann Rheum Dis. (1996) 55:559-60. doi: 10.1136/ard.55.8.559-b

117. Suwalsky M, Sánchez I, Bagnara M, Sotomayor CP. Interaction of antiarrhythmic drugs with model membranes. Biochim Biophys Acta. (1994) 1195:189-96. doi: 10.1016/0005-2736(94)90255-0

118. Nussio MR, Sykes MJ, Miners JO, Shapter JG. Kinetics membrane disruption due to drug interactions of chlorpromazine hydrochloride. Langmuir. (2009) 25:1086-90. doi: 10.1021/la803288s

119. Lillicrap DP, Pinto M, Benford K, Ford PM, Ford S. Heterogeneity of laboratory test results for antiphospholipid antibodies in patients treated with chlorpromazine and other phenothiazines. Am J Clin Pathol. (1990) 93:771-5. doi: 10.1093/ajcp/93.6.771

120. Delluc A, Rousseau A, Le Galudec M, Canceil O, Woodhams B, Etienne $\mathrm{S}$, et al. Prevalence of antiphospholipid antibodies in psychiatric patients users and non-users of antipsychotics. Br J Haematol. (2014) 164:272-9. doi: 10.1111/bjh.12627

121. Aminov RI. Biotic acts of antibiotics. Front Microbiol. (2013) 4:241. doi: 10.3389/fmicb.2013.00241

122. Vyse T, So AK. Sulphasalazine induced autoimmune syndrome. $\mathrm{Br} J$ Rheumatol. (1992) 31:115-6. doi: 10.1093/rheumatology/31.2.115

123. Graham LE, Bell AL. Minocycline-associated lupus-like syndrome with ulnar neuropathy and antiphospholipid antibody. Clin Rheumatol. (2001) 20:67-9. doi: $10.1007 / \mathrm{s} 100670170108$

124. Risse J, Vieira M, Beuret F, Petitpain N, Zuily S, Wahl D. Reversible drug-induced antiphospholipid syndrome. Lupus. (2018) 27:333-5. doi: 10.1177/0961203317712463

125. Gross RL, Brucker J, Bahce-Altuntas A, Abadi MA, Lipoff J, Kotlyar D, et al. A novel cutaneous vasculitis syndrome induced by levamisole-contaminated cocaine. Clin Rheumatol. (2011) 30:1385-92. doi: $10.1007 /$ s10067-011-1805-3
126. Magro CM, Wang X. Cocaine-associated retiformpurpura: a C5b-9mediated microangiopathy syndrome associated with enhanced apoptosis and high levels of intercellular adhesion molecule-1 expression. Am J Dermatopathol. (2013) 35:722-30. doi: 10.1097/DAD.0b013e31827eaf0b

127. Souied O, Baydoun H, Ghandour Z, Mobarakai N. Levamisole-contaminated cocaine: an emergent cause of vasculitis and skin necrosis. Case Rep Med. (2014) 2014:434717. doi: 10.1155/2014/434717

128. Lúcio M, Lima JL, Reis S. Drug-membrane interactions: significance for medicinal chemistry. Curr Med Chem. (2010) 17:1795-809. doi: $10.2174 / 092986710791111233$

129. Calder PC. Feeding the immune system. Proc Nutr Soc. (2013) 72:299-309. doi: 10.1017/S0029665113001286

130. Reifen R, Blank M, Afek A, Kopilowiz Y, Sklan D, Gershwin ME, et al. Dietary polyunsaturated fatty acids decrease anti-dsDNA and anti-cardiolipin antibodies production in idiotype induced mouse model of systemic lupus erythematosus. Lupus. (1998) 7:192-7. doi: 10.1191/096120398678919985

131. Vojdani A. A potential link between environmental triggers and autoimmunity. Autoimmune Dis. (2014) 2014:437231. doi: $10.1155 / 2014 / 437231$

132. Wolowczuk I, Verwaerde C, Viltart O, Delanoye A, Delacre M, Pot B, et al. Feeding our immune system: impact on metabolism. Clin Dev Immunol. (2008) 2008:639803. doi: 10.1155/2008/639803

133. Marion-Letellier R, Savoye G, Ghosh S. Polyunsaturated fatty acids and inflammation. IUBMB Life. (2015) 67:659-67. doi: 10.1002/iub.1428

134. Mizutani H, Engelman RW, Kinjoh K, Kurata Y, Ikehara S, Matsuzawa Y, et al. Calorie restriction prevents the occlusive coronary vascular disease of autoimmune (NZW x BXSB)F1 mice. Proc Natl Acad Sci USA. (1994) 91:4402-6. doi: 10.1073/pnas.91.10.4402

135. Anderson RM, Weindruch R. Metabolic reprogramming, caloric restriction and aging. Trends Endocrinol Metab. (2010) 21:134-41. doi: 10.1016/j.tem.2009.11.005

136. Riancho-Zarrabeitia L, Cubería M, Muñoz P, López-Hoyos M, García-Canale S, García-Unzueta M, et al. Vitamin D and antiphospholipid syndrome: a retrospective cohort study and meta-analysis. Semin Arthritis Rheum. (2018) 47:877-82. doi: 10.1016/j.semarthrit.2017.10.007

137. Agmon-Levin N, Blank M, Zandman-Goddard G, Orbach H, Meroni PL, Tincani A, et al. Vitamin D: an instrumental factor in the anti-phospholipid syndrome by inhibition of tissue factor expression. Ann Rheum Dis. (2011) 70:145-50. doi: 10.1136/ard.2010.134817

138. Gysler SM, Mulla MJ, Stuhlman M, Sfakianaki AK, Paidas MJ, Stanwood $\mathrm{NL}$, et al. Vitamin D reverses aPL-induced inflammation and LMWHinduced sFlt-1 release by human trophoblast. Am J Reprod Immunol. (2015) 73:242-50. doi: 10.1111/aji.12301

139. Gharavi EE, Chaimovich H, Cucurull E, Celli CM, Tang H, Wilson WA, et al. Induction of antiphospholipid antibodies by immunization with synthetic viral and bacterial peptides. Lupus. (1999) 8:449-55. doi: 10.1177/096120339900800607

140. Blank M, Shoenfeld Y, Cabilli S, Heldman Y, Fridkin M, Katchalski-Katzir E. Prevention of experimental antiphospholipid syndrome and endothelial cell activation by synthetic peptides. Proc Natl Acad Sci USA. (1999) 96:5164-8. doi: 10.1073/pnas.96.9.5164

141. Blank M, Krause I, Fridkin M, Keller N, Kopolovic J, Goldberg I, et al. Bacterial induction of autoantibodies to beta2-glycoprotein- I accounts for the infectious etiology of antiphospholipid syndrome. J Clin Invest. (2002) 109:797-804. doi: 10.1172/JCI0212337

142. van Os GM, Meijers JC, Agar Ç, Seron MV, Marquart JA, Åkesson P, et al. Induction of anti- $\beta 2$-glycoprotein $\mathrm{I}$ autoantibodies in mice by protein H of Streptococcus pyogenes. J Thromb Haemost. (2011) 9:2447-56. doi: 10.1111/j.1538-7836.2011.04532.x

143. Kuwana M, Matsuura E, Kobayashi K, Okazaki Y, Kaburaki J, Ikeda $\mathrm{Y}$, et al. Binding of beta 2-glycoprotein I to anionic phospholipids facilitates processing and presentation of a cryptic epitope that activates pathogenic autoreactive $\mathrm{T}$ cells. Blood. (2005) 105:1552-7. doi: 10.1182/blood-2004-08-3145

144. Yamaguchi Y, Seta N, Kaburaki J, Kobayashi K, Matsuura E, Kuwana M. Excessive exposure to anionic surfaces maintains autoantibody response to beta(2)-glycoprotein I in patients with antiphospholipid syndrome. Blood. (2007) 110:4312-8. doi: 10.1182/blood-2007-07-100008 
145. Ryan BJ, Nissim A, Winyard PG. Oxidative post-translational modifications and their involvement in the pathogenesis of autoimmune diseases. Redox Biol. (2014) 2:715-24. doi: 10.1016/j.redox.2014.05.004

146. Matsuura E, Lopez LR. Are oxidized LDL/beta2-glycoprotein I complexes pathogenic antigens in autoimmune-mediated atherosclerosis? Clin Dev Immunol. (2004) 11:103-11. doi: 10.1080/10446670410001722186

147. Giannakopoulos B, Krilis SA. The pathogenesis of the antiphospholipid syndrome. N Engl J Med. (2013) 14:1033-44. doi: 10.1056/NEJMra1112830

148. de Laat B, van Berkel M, Urbanus RT, Siregar B, de Groot PG, Gebbink $\mathrm{MF}$, et al. Immune responses against domain $\mathrm{I}$ of $\beta(2)$-glycoprotein I are driven by conformational changes: domain I of $\beta(2)$-glycoprotein I harbors a cryptic immunogenic epitope. Arthritis Rheum. (2011) 63:3960-8. doi: 10.1002/art.30633

149. Iverson GM, Reddel S, Victoria EJ, Cockerill KA, Wang YX, Marti-Renom MA, et al. Use of single point mutations in domain I of b2-glycoprotein I to determine fine antibody specificity of antiphospholipid autoantibodies. $J$ Immunol. (2002) 169:7097-103. doi: 10.4049/jimmunol.169.12.7097

150. Ioannou Y, Pericleous C, Giles I, Latchman DS, Isenberg DA, Rahman A. Binding of antiphospholipid antibodies to discontinuous epitopes on domain I of human beta(2)-glycoprotein I: mutation studies including residues R39 to R43. Arthritis Rheum. (2007) 56:280-90. doi: 10.1002/art.22306

151. de Laat B, Pengo V, Pabinger I, Musial J, Voskuyl AE, Bultink IE, et al. The association between circulating antibodies against domain I of beta2glycoprotein I and thrombosis: an international multicenter study. J Thromb Haemost. (2009) 7:1767-73. doi: 10.1111/j.1538-7836.2009.03588.x

152. Pengo V, Ruffatti A, Tonello $M$, Cuffaro S, Banzato A, Bison E. Antiphospholipid syndrome: antibodies to Domain 1 of $\beta 2$-glycoprotein 1 correctly classifypatients at risk. J Thromb Haemost. (2015) 13:782-7. doi: $10.1111 /$ jth. 12865

153. Iwaniec T, Kaczor MP, Celinska-Löwenhoff M, Polanski S, Musiał J. Clinical significance of anti-domain $1 \quad \beta 2$-glycoprotein I antibodies in antiphospholipid syndrome. Thromb Res. (2017) 153:90-4. doi: 10.1016/j.thromres.2017.02.019

154. Guo H, Zhang Y, Li A, Wang C, Yang S, Zhang Y, et al. Anti-domain 1 of beta2-glycoprotein I aids risk stratification in lupus anticoagulant-positive patients. Clin Exp Med. (2019). doi: 10.1007/s10238-019-00555-w. [Epub ahead of print].
155. Durigutto P, Grossi C, Borghi MO, Macor P, Pregnolato F, Raschi E, et al. New insight into antiphospholipid syndrome: antibodies to $\beta 2$ glycoprotein I-domain 5 fail to induce thrombi in rats. Haematologica. (2019) 104:819-26. doi: 10.3324/haematol.2018.198119

156. Andreoli L, Fredi M, Nalli C, Franceschini F, Meroni PL, Tincani A. Antiphospholipid antibodies mediate autoimmunity against dying cells. Autoimmunity. (2013) 46:302-6. doi: 10.3109/08916934.2013.783025

157. Shoenfeld Y, Blank M, Cervera R, Font J, Raschi E, Meroni PL. Infectious origin of the antiphospholipid syndrome. Ann Rheum Dis. (2006) 65:2-6. doi: 10.1136/ard.2005.045443

158. Hansen KE, Kong DF, Moore KD, Ortel TL. Risk factors associated with thrombosis in patients with antiphospholipid antibodies. J Rheumatol. (2001) 28:2018-24.

159. Girón-González JA, García del Río E, Rodríguez C, Rodríguez-Martorell J, Serrano A. Antiphospholipid syndrome and asymptomatic carriers of antiphospholipid antibody: prospective analysis of 404 individuals. $J$ Rheumatol. (2004) 31:1560-7.

160. Aslani S, Mahmoudi M, Karami J, Jamshidi AR, Malekshahi Z, Nicknam MH. Epigenetic alterations underlying autoimmune diseases. Autoimmunity. (2016) 49:69-83. doi: 10.3109/08916934.2015.1134511

161. Schmidl C, Delacher M, Huehn J, Feuerer M. Epigenetic mechanisms regulating T-cell responses. J Allergy Clin Immunol. (2018) 142:728-43. doi: 10.1016/j.jaci.2018.07.014

162. Wu H, Deng Y, Feng Y, Long D, Ma K, Wang X, et al. Epigenetic regulation in B-cell maturation and its dysregulation in autoimmunity. Cell Mol Immunol. (2018) 15:676-84. doi: 10.1038/cmi.2017.133

Conflict of Interest Statement: The authors declare that the research was conducted in the absence of any commercial or financial relationships that could be construed as a potential conflict of interest.

Copyright (c) 2019 Martirosyan, Aminov and Manukyan. This is an open-access article distributed under the terms of the Creative Commons Attribution License (CC $B Y)$. The use, distribution or reproduction in other forums is permitted, provided the original author(s) and the copyright owner(s) are credited and that the original publication in this journal is cited, in accordance with accepted academic practice. No use, distribution or reproduction is permitted which does not comply with these terms. 